\title{
Evaluasi Jerami Sorgum Varietas Samurai 2 Hasil Iradiasi Gamma secara In Sacco
}

\section{In Sacco Evaluation of Gamma Irradiated Samurai 2 Sorghum Straw}

\author{
Teguh Wahyono ${ }^{1}$, Widia Apriliani ${ }^{2}$, Anna Muawanah ${ }^{2}$ dan Sihono ${ }^{1}$ \\ ${ }^{1}$ Pusat Aplikasi Isotop dan Radiasi, BATAN \\ Jl. Lebak Bulus Raya No. 49, Jakarta 12440 \\ ${ }^{2}$ Fakultas Sains dan Teknologi, Universitas Islam Negeri Syarif Hidayatullah \\ Jl. Ir. H. Juanda No. 95, Tangerang Selatan, Banten, 15412 \\ Email : teguhwahyono@batan.go.id
}

\begin{abstract}
ABSTRAK
Studi in sacco dilakukan untuk mengevaluasi pengaruh iradiasi gamma terhadap degradasi dan produk fermentasi rumen dari substrat jerami sorgum varietas Samurai 2. Dosis iradiasi yang digunakan sebesar 0, 100 dan $150 \mathrm{kGy}$ bersumber dari cobalt-60. Metode yang digunakan adalah evaluasi secara in sacco dengan titik pengambilan parameter pada jam ke-0, 12, 24, 48 dan 72. Variabel yang diamati adalah degradasi Bahan Kering (BK), karakteristik degradasi BK, degradasi Bahan Organik (BO), karakteristik degradasi $\mathrm{BO}$ dan produk fermentasi rumen. Produk fermentasi rumen yang diamati meliputi kondisi $\mathrm{pH}$, konsentrasi amoniak $\left(\mathrm{NH}_{3}\right)$ dan produksi volatile fatty acid (VFA) total. Penelitian ini menggunakan rancangan acak lengkap (RAL) dengan tiga perlakuan dan lima ulangan. Hasil penelitian menunjukkan bahwa pada periode inkubasi ke-72 jam, dosis iradiasi $150 \mathrm{kGy}$ mampu meningkatkan degradasi BK sebesar 21,66\% dibandingkan kontrol dan 12,09\% dibandingkan dosis 100 kGy $(\mathrm{P}<0,05)$. Perlakuan iradiasi gamma dapat meningkatkan nilai degradasi maksimum $(\mathrm{a}+\mathrm{b}) \mathrm{BK}$ pada jerami sorgum varietas Samurai $2(\mathrm{P}<0,05)$. Perlakuan iradiasi gamma dosis $150 \mathrm{kGy}$ juga mempengaruhi karakteristik degradasi BO yaitu peningkatan parameter degradasi efektif (DE) pada nilai k 0,02 $(\mathrm{P}<0,05)$. Perlakuan iradiasi gamma dapat meningkatkan kondisi $\mathrm{pH}$ dan konsentrasi $\mathrm{NH}_{3}(\mathrm{P}<0,05)$. Kesimpulan dari penelitian ini adalah bahwa Iradiasi gamma dosis 100 dan $150 \mathrm{kGy}$ mampu meningkatkan degradasi BK dan BO. Dosis radiasi $150 \mathrm{kGy}$ merupakan dosis terbaik untuk meningkatkan degradasi BK maksimum $(\mathrm{a}+\mathrm{b})$.
\end{abstract}

Kata kunci: Degradasi bahan kering, In sacco, Iradiasi gamma, Jerami sorgum

\begin{abstract}
In sacco study was done to evaluate the effects of gamma irradiation on degradability and rumen fermentation product of Samurai 2 sorghum straw variety. The level doses of 0,100 and $150 \mathrm{kGy}$ from cobalt-60 gamma rays irradiator was used for treatment. Samples were incubated in fistulated buffalo for periods $0,12,24,48$ and 72 with in sacco method. The observed parameters were the degradations of dry matter (DM) and organic matter (OM). Rumen fermentation products, DM and OM degradation characteristics also observed. Rumen fermentation products parameters were $\mathrm{pH}$, ammonia $\left(\mathrm{NH}_{3}\right)$ and total volatile fatty acid (VFA). Complete randomized design (CRD) (three treatments and five replications) was used to analyze data. The results showed that gamma irradiation dose of $150 \mathrm{kGy}$ was able to increase the degradation of DM by $21.66 \%$ compared to control and $12.09 \%$ compared to $100 \mathrm{kGy}(\mathrm{P}<0.05)$ in $72 \mathrm{~h}$ incubation period. Dose of $150 \mathrm{kGy}$ increase the $(\mathrm{a}+\mathrm{b})$ constanta (maximum DM degradation) $(\mathrm{P}<0.05)$. Dose of $150 \mathrm{kGy}$ increase the the effective degradability (ED) OM parameter for k $0.02(\mathrm{P}<0.05)$. Dose of $150 \mathrm{kGy}$ improve $\mathrm{pH}$ condition and $\mathrm{NH}_{3}$ concentration $(\mathrm{P}<0.05)$. Gamma irradiation dose of 100 and 150 $\mathrm{kGy}$ were able to increase degradation of DM and OM. The dose of $150 \mathrm{kGy}$ was the best dose to increase maximum DM degradation.
\end{abstract}

Keywords : Dry matter degradation, Gamma irradiation, In sacco, Sorghum straw

\section{PENDAHULUAN}

Ternak ruminansia membutuhkan sumber serat yang banyak diperoleh dari limbah pertanian.
Limbah pertanian yang biasa dimanfaatkan untuk pakan ternak adalah jerami. Jerami yang dimanfaatkan diantaranya jerami padi, jagung, gandum dan sorgum. Budidaya sorgum mulai 
gencar di lakukan di Indonesia sebagai upaya pemenuhan diversifikasi pangan. Tanaman sorgum merupakan komoditas tanaman yang cocok dikembangan di lahan marginal karena kebutuhan airnya yang sedikit [1]. Tanaman sorgum memiliki palatabilitas yang baik sebagai sumber serat dan mengandung protein kasar yang dapat mencapai $12,8 \%$ [2]. Hal tersebut memberi peluang pemanfaatan jerami sorgum sebagai limbah pertanian untuk hijauan pakan ternak. Varietas sorgum Samurai 2 adalah varietas hasil pengembangan BATAN yang memiliki keunggulan produktivitas tinggi, biomasa $47 \mathrm{t} / \mathrm{ha}$, kebal terhadap penyakit karat daun dan busuk pelepah [3]. Berbagai kelebihan tersebut sangat mendukung untuk menjadikan jerami sorgum sebagai sumber serat ruminansia.

Hal yang perlu diperhatikan dalam penggunaan jerami sebagai pakan ternak adalah adanya ikatan antara lignin dengan selulosa dan hemiselulosa [4]. WAHYONO et al. [5] menjelaskan bahwa keterikatan selulosa atau hemiselulosa dengan matriks lignin akan menghambat proses hidrolisis oleh enzim di dalam rumen sehingga akan menghambat proses pencernaan. Berbagai studi dilakukan untuk menurunkan pengaruh ikatan matriks lignin utuk meningkatkan proses degradasi pakan di dalam rumen. Studi yang pernah dilakukan diantaranya dengan menambahkan asam-asam kuat atau alkali seperti $\mathrm{NaOH}$ dan $\mathrm{Ca}(\mathrm{OH})_{2}$ untuk meningkatkan degradasi selulosa pada bahan pakan [6] serta memanfaatkan mikroorganisme seperti Neurospora crassa dan Fusarium oxysporum [7]. Berbagai metode di atas memiliki potensi berbahaya bagi tubuh ternak dan lingkungan pada umumnya.

Pre-treatment dengan iradiasi gamma merupakan alternatif metode untuk meningkatkan nilai nutrisi pakan ternak. Penyinaran dengan sinar gamma dapat memutuskan ikatan senyawa lignin dan hemiselulosa sehingga akan meningkatkan kecernaan bahan pakan [8]. WANG et al. [9] melakukan penelitian pre-treatment menggunakan iradiasi gamma terhadap limbah pertanian. WAHYONO et al. [5] melaporkan bahwa dosis iradiasi gamma sebesar $100 \mathrm{kGy}$ dapat meningkatkan degradasi in sacco bagas sorgum. WAHYONO dan FIRSONI [10] melaporkan bahwa dosis $100 \mathrm{kGy}$ mampu meningkatkan nilai nutrisi dan kecernaan in vitro pada bagas sorgum. Dari berbagai referensi diatas, belum terdapat informasi mengenai pengaruh iradiasi gamma terhadap degradasi jerami sorgum varietas Samurai 2. Dosis radiasi yang perlu diteliti adalah 100 dan 150 kGy yang berdasar dari berbagai penelitian terdahulu. Evaluasi degradasi pakan dapat dilakukan dengan berbagai metode, salah satunya adalah metode in sacco. Metode in sacco memiliki kelebihan dapat mengetahui laju degradasi bahan pakan pada waktu tertentu [11]. Tujuan dari penelitian ini adalah untuk mengetahui pengaruh iradiasi gamma terhadap degradasi in sacco dan produk fermentasi rumen pada jerami sorgum varietas Samurai 2.

\section{BAHAN DAN METODE}

\section{Preparasi bahan}

Penelitian ini menggunakan bahan sorgum (Sorghum bicolor) varietas Samurai 2 yang ditanam di kebun percobaan PAIR BATAN. Sorgum dipanen pada umur 80 hari. Bagian tanaman yang digunakan adalah bagian jerami yang meliputi bagian daun dan batang. Jerami sorgum dikeringkan di udara terbuka kemudian dikeringkan di oven selama dua malam pada suhu $60^{\circ} \mathrm{C}$. Bahan yang telah kering kemudian digiling dan disaring sampai berukuran $2 \mathrm{~mm}$. Iradiasi jerami sorgum dilakukan di fasilitas iradiasi gamma, Pusat Aplikasi Isotop dan Radiasi BATAN. Iradiasi menggunakan sumber Co-60 dengan laju dosis $3,7 \mathrm{kGy} / \mathrm{jam}$. Jerami sorgum dikemas dalam plastik polyethylene dan dipapar radiasi 100 dan $150 \mathrm{kGy}$ dengan laju dosis 20 $\mathrm{kGy} / \mathrm{jam}$. Pengujian in sacco dilaksanakan di Laboratorium Nutrisi Ternak, Bidang Pertanian PAIR BATAN.

\section{Studi in sacco}

Pengujian in sacco dilakukan dengan metode ØRSKOV \& McDONALD [12]. Ternak yang digunakan adalah kerbau jantan berfistula yang dipelihara dalam kandang individu $\left(5 \times 3 \mathrm{~m}^{2}\right)$ dengan alas lantai semen yang dibersihkan secara berkala. Ransum kerbau diberikan sesuai kebutuhan berat badan. Komposisi ransum kerbau berupa rumput lapangan $(70 \%)$ dan konsentrat (30\%) dalam Bahan Kering (BK).

Kantong nilon $\left(8 \times 15 \mathrm{~cm}^{2}\right)$ berpori $30 \mu \mathrm{m}$ diisi sampel pakan sebanyak 4,5 g. Kantong nilon yang telah berisi sampel kemudian diinkubasi di dalam fistula sebelum kerbau diberi pakan pada pagi hari (08.00 WIB). Inkubasi dilakukan pada periode $0,12,24,48$ dan 72 jam. Sampel yang 
telah diinkubasi kemudian dibilas menggunakan air mengalir dan dikeringkan. Sampel dimasukkan ke dalam oven suhu $60^{\circ} \mathrm{C}$ selama 48 jam untuk memperoleh berat BK. Sampel dalam bentuk BK kemudian dianalisis kandungan Bahan Organik (BO). Peubah yang diamati adalah degradasi BK, karakteristik degradasi BK, degradasi BO dan karakteristik degradasi BO.

\section{Analisis statistik}

Penelitian ini menggunakan Rancangan Acak Lengkap (RAL) dengan tiga perlakuan dan lima ulangan. Model statistik yang digunakan adalah sebagai berikut:

$$
\mathrm{Y}_{\mathrm{ij}}=\mu+\alpha_{\mathrm{i}}+\varepsilon_{\mathrm{ij}}
$$

Y adalah variable terikat, $\mu$ adalah rerata perlakuan, $\alpha_{i}$ adalah pengaruh dari perlakuan iradiasi gamma sedangkan $\varepsilon_{i j}$ adalah pengaruh acak/faktor error. Data yang diperoleh dianalisis dengan analisis ragam analysis of variance (ANOVA) dilanjutkan dengan uji Duncan's Multiple Range Test [13] pada taraf kepercayaan $\mathrm{P}<0,05$. Analisis data menggunakan program SPSS 20.

Karakteristik degradasi BK dan BO dikalkulasi menggunakan metode eksponensial ØRSKOV and McDONALD [12] menggunakan program NEWAY® berdasarkan persamaan: $\mathrm{P}=\mathrm{a}+\mathrm{b}\left(1-\mathrm{e}^{-\mathrm{ct}}\right)$. Nilai degradasi efektif (DE) dikalkulasi berdasarkan model matematis Agricultural and Food Research Council [14]: $\mathrm{DE}=\mathrm{a}+\{(\mathrm{bc}) /(\mathrm{c}+\mathrm{k})\}$. Konstanta a adalah fraksi yang mudah larut. Konstanta $\mathrm{b}$ adalah fraksi yang tidak larut namun dapat terdegradasi. Konstanta c adalah laju kelarutan fraksi secara konstan per $\mathrm{t}$ satuan waktu. Konstanta $\mathrm{k}$ adalah laju tingkat kelolosan fraksi pakan (\%/jam).

\section{HASIL DAN PEMBAHASAN}

\section{Degradasi BK}

Hasil pengamatan degradasi $\mathrm{BK}$ dan karakteristik degradasi BK pada periode 0-72 jam dapat dilihat pada Tabel 1 dan Tabel 2. Pada penagamatan jam ke-0, terlihat bahwa perlakuan iradiasi dosis $100 \mathrm{kGy}$ menghasilkan degradasi BK yang paling tinggi disusul oleh perlakuan dosis $150 \mathrm{kGy}$ dan kontrol $(\mathrm{P}<0,05)$. Pada periode inkubasi ke-72 jam, dosis iradiasi $150 \mathrm{kGy}$ mampu meningkatkan degradasi BK sebesar $21,66 \%$ dibandingkan kontrol dan 12,09\% dibandingkan dosis 100 kGy $\quad(\mathrm{P}<0,05)$. Karakteristik degradasi merupakan representasi dari fraksi-fraksi yang terdapat dalam pakan berdasarkan metode eksponensial ØRSKOV and McDONALD [12]. Pada Tabel 2 dapat dilihat bahwa semakin tinggi dosis iradiasi dapat mempengaruhi nilai degradasi fraksi $\mathrm{b}(\mathrm{P}<0,05)$. Fraksi b adalah fraksi pakan yang tidak larut namun dapat terdegradasi. Perlakuan iradiasi gamma juga dapat meningkatkan degradasi maksimum (fraksi $a+b)$ pada jerami sorgum varietas Samurai $2 \quad(\mathrm{P}<0,05)$. Nilai $\mathrm{DE}$ tidak berbeda nyata antar perlakuan.

Bahan kering merupakan komponen pakan ternak yang sudah tidak mengandung air sehingga kecernaan bahan kering menjadi indikator derajat degradasi pakan [11]. Pada Tabel terlihat bahwa waktu inkubasi yang semakin lama akan mengurangi jumlah substrat. Hal tersebut menandakan laju degradasi yang berbanding lurus dengan ketersediaan substrat [15]. ZULKARNAIN et al. [16] melaporkan bahwa degradasi pakan akan semakin meningkat seiring dengan berkurangnya ketersediaan substrat pakan yang diamati. Hal tersebut karena meningkatnya aktivitas mikroba di dalam rumen.

Tabel 1. Degradasi BK (\%) hasil inkubasi jerami sorgum secara in sacco pada periode 0-72 jam

\begin{tabular}{lccccc}
\hline \multirow{2}{*}{ Perlakuan } & \multicolumn{5}{c}{ Degradasi BK (\%) } \\
\cline { 2 - 6 } & 0 & 12 & 24 & 48 & 72 \\
\cline { 2 - 6 } & $2,16^{\mathrm{a}}$ & 23,56 & 36,55 & 43,24 & $45,16^{\mathrm{a}}$ \\
Kontrol & $4,48^{\mathrm{b}}$ & 20,20 & 29,97 & 43,78 & $49,01^{\mathrm{b}}$ \\
$100 \mathrm{kGy}$ & $1.89^{\mathrm{a}}$ & 19,93 & 31,42 & 44,57 & $54,94^{\mathrm{c}}$ \\
SEM & 0,494 & 0,824 & 1,584 & 0,718 & 0,994 \\
\hline
\end{tabular}

Keterangan : Kontrol: jerami sorgum tanpa perlakuan iradiasi gamma; 100 kGy: jerami sorgum perlakuan iradiasi gamma dosis $100 \mathrm{kGy} ; 150 \mathrm{kGy}$ : jerami sorgum perlakuan iradiasi gamma dosis 150 kGy; SEM : Standard Error Mean; superscript berbeda pada kolom yang sama menunjukkan perbedaan yang nyata $(\mathrm{P}<0,05)$. 
Tabel 2. Karakteristik degradasi BK hasil inkubasi jerami sorgum secara in sacco pada periode 0-72 jam

\begin{tabular}{lcccc}
\hline \multirow{2}{*}{ Parameter } & \multicolumn{3}{c}{ Perlakuan } & \multirow{2}{*}{ SEM } \\
\cline { 2 - 4 } & Kontrol & $100 \mathrm{kGy}$ & $150 \mathrm{kGy}$ & 0,534 \\
$\mathrm{a}$ & 1,94 & 4,24 & 2,17 & 1,771 \\
$\mathrm{~b}$ & $44,03^{\mathrm{a}}$ & $48,93^{\mathrm{b}}$ & $56,94^{\mathrm{c}}$ & 1,861 \\
$\mathrm{a}+\mathrm{b}$ & $45,98^{\mathrm{a}}$ & $53,17^{\mathrm{b}}$ & $59,11^{\mathrm{c}}$ & 0,005 \\
$\mathrm{c}(/$ jam$)$ & $0,060^{\mathrm{b}}$ & $0,036^{\mathrm{a}}$ & $0,031^{\mathrm{a}}$ & \\
Degradasi Efektif (DE) pada nilai k yang berbeda & 34,12 & 36,15 & 0,651 \\
$\mathrm{k}=0,02$ & 34,92 & 23,63 & 23,46 & 0,688 \\
$\mathrm{k}=0,05$ & 25,92 & & \\
\hline
\end{tabular}

Keterangan : Kontrol: jerami sorgum tanpa perlakuan iradiasi gamma; 100 kGy: jerami sorgum perlakuan iradiasi gamma dosis $100 \mathrm{kGy}$; $150 \mathrm{kGy}$ : jerami sorgum perlakuan iradiasi gamma dosis 150 kGy; SEM : Standard Error Mean; superscript berbeda pada baris yang sama menunjukkan perbedaan yang nyata $(\mathrm{P}<0,05)$; a: fraksi mudah larut; b: fraksi tidak larut tetapi dapat terdegradasi; c: laju degradasi fraksi per t satuan waktu; k: laju tingkat kelolosan fraksi pakan (\%/jam).

Perlakuan iradiasi gamma pada dosis 100 dan $150 \mathrm{kGy}$ terbukti mampu meningkatkan degradasi BK pada periode inkubasi jam ke-72. Hal tersebut karena pengaruh pemutusan ikatan lignohemiselulosa dan lignoselulosa sehingga meningkatkan nilai degradasi bahan kering pada jerami sorgum. WAHYONO et al. [5] melaporkan bahwa pemutusan ikatan lignin dengan selulosa atau hemiselulosa dapat meningkatkan rasio dari lignoselulosa menjadi serat kasar sehingga nilai degradasinya juga semakin tinggi. Iradiasi gamma dapat merusak ikatan lignoselulosa pada produk sisa pertanian menjadi molekul yang lebih kecil sehingga fragmen dari lignin dan monomer karbohidrat bisa lepas melalui pori-pori pada kantong nilon $[5,17]$. Pernyataan tersebut dapat diamati pada meningkatnya fraksi $b$ akibat perlakuan iradiasi gamma pada dosis 100 dan 150 kGy (Tabel 2). Fraksi b adalah representasi dari fraksi yang tidak larut air tetapi dapat terdegradasi oleh mikroba rumen. SAINI et al. [18] juga melaporkan bahwa iradiasi sinar gamma bisa menganggu ikatan lignoselulosa yang kompleks untuk membuka ikatan polimernya. SHAHBAZI et al. [8] melaporkan bahwa iradiasi gamma pada dosis 50 - $150 \mathrm{kGy}$ pada alfalfa hay dapat meningkatkan degradasi bahan kering dan NDF. Hal yang sama juga dilaporkan WAHYONO et al. [5] yang menyatakan bahwa sorgum Samurai 1 yang diiradiasi dengan dosis $100 \mathrm{kGy}$ mulai mengalami peningkatan dibandingkan dengan dosis $50 \quad \mathrm{kGy}$ setelah 24 jam inkubasi. SIDDHURAJU et al. [19] menjelaskan bahwa irradiasi gamma dosis tinggi dapat digunakan untuk meningkatkan degradabilitas dari serat kasar pada berbagai limbah industri pertanian termasuk jerami.

\section{Degradasi BO}

Hasil pengamatan degradasi $\mathrm{BO}$ dan karakteristik degradasi $\mathrm{BO}$ dapat dilihat pada Tabel 3 dan 4. Peningkatan degradasi BO akibat perlakuan iradiasi mulai terlihat setelah periode inkubasi ke-48 jam. Dosis iradiasi 100 dan 150 kGy dapat meningkatkan degradasi BO jerami sorgum masing-masing sebesar 8,35 dan $12,82 \%$ $(\mathrm{P}<0,05)$ pada periode inkubasi ke-48 jam. Pada periode inkubasi ke-72 jam, nilai degradasi BO tertinggi dihasilkan oleh jerami sorgum yang diiradiasi gamma pada dosis $150 \mathrm{kGy}(\mathrm{P}<0,05)$. Karakteristik degradasi BO terlihat memiliki pola yang sama dengan karakteristik degradasi BK yaitu terdapat kenaikan fraksi $b$ dan fraksi $(a+b)$ setelah perlakuan iradiasi gamma $(\mathrm{P}<0,05)$. Hal yang berbeda adalah terdapat peningkatan parameter DE pada nilai k 0,02 setelah perlakuan iradiasi $150 \mathrm{kGy}(\mathrm{P}<0,05)$.

Degradasi BO penting untuk diamati karena bahan tersebut adalah total bahan yang difermentasi mikroba rumen untuk menghasilkan sumber energi bagi ternak [20]. Degradasi BO merupakan indikator yang berhubungan erat dengan dengan degradasi BK karena sebagian bahan kering terdiri atas bahan organik [21]. Hal tersebut menjelaskan relevansi hasil pada degradasi BO yang memiliki pola yang sama dengan degradasi BK (Tabel 1). Pola yang sedikit berbeda terlihat pada karakteristik degradasi BO 
Tabel 3. Degradasi BO (\%) hasil inkubasi jerami sorgum secara in sacco pada periode 0-72 jam

\begin{tabular}{lccccc}
\hline \multirow{2}{*}{ Perlakuan } & \multicolumn{5}{c}{ Degradasi BO (\%) } \\
\cline { 2 - 6 } & 0 & 12 & 24 & 48 & 72 \\
\cline { 2 - 5 } & 7,93 & $28,06^{\mathrm{b}}$ & 37,79 & $42,97^{\mathrm{a}}$ & $47,12^{\mathrm{a}}$ \\
Kontrol & 9,19 & $24,73^{\mathrm{ab}}$ & 33,31 & $46,56^{\mathrm{ab}}$ & $50,54^{\mathrm{b}}$ \\
$100 \mathrm{kGy}$ & 9,83 & $24,15^{\mathrm{a}}$ & 36,73 & $48,48^{\mathrm{b}}$ & $55,26^{\mathrm{c}}$ \\
$150 \mathrm{kGy}$ & 0,768 & 0,790 & 1,283 & 1,057 & 1,109 \\
SEM & &
\end{tabular}

Keterangan : Kontrol: jerami sorgum tanpa perlakuan iradiasi gamma; 100 kGy: jerami sorgum perlakuan iradiasi gamma dosis $100 \mathrm{kGy} ; 150 \mathrm{kGy}$ : jerami sorgum perlakuan iradiasi gamma dosis 150 kGy; SEM : Standard Error Mean; superscript berbeda pada kolom yang sama menunjukkan perbedaan yang nyata $(\mathrm{P}<0,05)$.

Tabel 4. Karakteristik degradasi BO hasil inkubasi jerami sorgum secara in sacco pada periode 0-72 jam

\begin{tabular}{lcccc}
\hline \multirow{2}{*}{ Parameter } & \multicolumn{3}{c}{ Perlakuan } & \multirow{2}{*}{ SEM } \\
\cline { 2 - 4 } \cline { 2 - 3 } Kontrol & $100 \mathrm{kGy}$ & $150 \mathrm{kGy}$ & 0,602 \\
$\mathrm{~b}$ & 8,09 & 9,09 & 9,63 & 1,895 \\
$\mathrm{a}+\mathrm{b}$ & $39,45^{\mathrm{a}}$ & $47,16^{\mathrm{b}}$ & $52,19^{\mathrm{b}}$ & 2,096 \\
$\mathrm{c}(/$ jam $)$ & $47,54^{\mathrm{a}}$ & $56,25^{\mathrm{b}}$ & $61,83^{\mathrm{b}}$ & 0,004 \\
Degradasi Efektif (DE) pada nilai k yang berbeda & $0,033^{\mathrm{a}}$ & $0,030^{\mathrm{a}}$ & \\
$\mathrm{k}=0,02$ & $37,31^{\mathrm{a}}$ & $37,80^{\mathrm{a}}$ & $40,58^{\mathrm{b}}$ & 0,614 \\
$\mathrm{k}=0,05$ & 29,17 & 27,30 & 28,17 & 0,544 \\
\hline
\end{tabular}

Keterangan : Kontrol: jerami sorgum tanpa perlakuan iradiasi gamma; 100 kGy: jerami sorgum perlakuan iradiasi gamma dosis $100 \mathrm{kGy} ; 150 \mathrm{kGy}$ : jerami sorgum perlakuan iradiasi gamma dosis 150 kGy; SEM : Standard Error Mean; superscript berbeda pada baris yang sama menunjukkan perbedaan yang nyata $(\mathrm{P}<0,05)$; a: fraksi mudah larut; b: fraksi tidak larut tetapi dapat terdegradasi; c: laju degradasi fraksi per t satuan waktu; k: laju tingkat kelolosan fraksi pakan (\%/jam).

dimana nilai fraksi $b$ dan $a+b$ pada perlakuan dosis $100 \mathrm{kGy}$ tidak berbeda dengan perlakuan dosis 150 kGy. Dalam hal tersebut dapat dijelaskan bahwa dosis 100 kGy sudah mampu meningkatkan nilai fraksi $\mathrm{b}$ pada jerami sorgum Samurai 2.

Dalam penelitian WAHYONO et al. [5] menjelaskan bahwa degradasi BK, BO dan NDF limbah industri pertanian berupa bagas sorgum dapat meningkat setelah perlakuan iradiasi gamma 100 kGy. Peningkatan tersebut mulai terjadi setelah periode inkubasi ke-72 jam. TANG et al. [22] juga melaporkan bahwa iradiasi gamma dapat meningkatkan degradasi BO pada jerami padi. Peningkatan degradasi BO dapat disebabkan oleh perubahan struktur biomassa akibat perlakuan iradiasi yaitu terjadinya cross-linking yang menyebabkan pemotongan pada polimer lignoselulosa [23]. Pengaruh degradasi dinding sel tanaman akibat pre-treatment juga dilaporkan mampu meningkatkan degradabilitas dari bahan organik jerami padi [22].

\section{KESIMPULAN}

Perlakuan iradiasi gamma mampu meningkatkan degradasi BK dan BO pada jerami sorgum varietas Samurai 2. Peningkatan degradasi terjadi pada jam inkubasi ke-72. Dosis iradiasi 150 kGy menghasilkan degradasi BK maksimum $(a+b)$ tertinggi.

\section{UCAPAN TERIMA KASIH}

Penulis mengucapkan terima kasih kepada seluruh staf Laboratorium Nutrisi Ternak dan Pemuliaan Tanaman Bidang Pertanian PAIR BATAN atas bantuan teknis selama penelitian. 
Penelitian ini dibiayai oleh anggaran PAIR BATAN.

\section{DAFTAR PUSTAKA}

1. Wahyono, T., Astuti, D.A, Wiryawan, K.G. dan Sugoro, I., Pengujian ransum kerbau berbahan baku sorgum sebagai sumber serat secara in vitro dan in sacco, $J$. Ilmiah Aplikasi Isotop dan Radiasi, vol. 10, pp. 113-126, 2014.

2. Oisat, Sorghum, Pan Germany Pestizid Aktions-Netzwerk E.V. Pan Germany, 2011.

3. Sihono, Human, S., Indriatama, W.M., Puspitasari W., Parno dan Carkum, Galur Mutan Sorgum PATIR-1 Berdaya Hasil Biji, Biomasa dan Gula Batang Tinggi serta Galur PATIR-4 Hasil Biji Tinggi Kualitas Baik, Perbaikan Proposal Pelepasan Varietas, Pusat Aplikasi Isotop dan Radiasi, BATAN, 2013.

4. Eun, J.S., Beauchemin, K.A., Hong, S.H. and Bauer, M.W., Exogenous enzymes added to untreated or ammoniated rice straw; effect on in vitro fermentation characteristic and degradability, J. Anim. Sci. And Tech, vol. 131, pp. 86-101, 2006.

5. Wahyono, T., Lelananingtyas N. and Sihono, Effects of gamma irradiation on ruminal degradation of samurai 1 sweet sorghum bagasse, Atom Indonesia, vol. 43, pp. 35-39, 2017.

6. Yan, Z., Li, J., Li, S., Cui, T., Jiang, Y., Cong, $\mathrm{G}$ and $\mathrm{Yu}, \mathrm{M}$. Impact of lignin content on the sweet sorghum bagasse enzymatic hydrolysis. Energy Procedia, vol. 61, pp. 1957-1960, 2014.

7. Dogaris, I., Karapati, S., Mamma, D., Kalogeris, E. and Kekos, D., Hydrothermal processing and enzymatic hydrolysis of sorghum bagasse for fermentable carbohydrates production,
Bioresour Technol, vol. 100, pp. 65436549, 2009.

8. Shahbazi, H.R., Sadeghi, A.A., Shawrang, P., and Raisali, G., Effects of gamma irradiation on ruminal $\mathrm{dm}$ and ndf degradation kinetics of alfalfa hay, Pakistan J. of Biological Science, vol 11, no. 8, pp. 1165-1168, 2008.

9. Wang, K.Q., Xiong, X.Y., Chen, J.P., Chen, L., Su, X. and Liu, Y., Comparison of gamma irradiation and steam explosion pretreatment for ethanol production from agricultural residues. Biomass and Bioenergy, vol. 46, pp. 301-308, 2012.

10. Wahyono, T. dan Firsoni, The changes of nutrient composition and in vitro evaluation on gamma irradiated sweet sorghum bagasse, J. Ilmiah Aplikasi Isotop dan Radiasi, vol. 12, pp. 69-79, 2016.

11. Wati, N. E., Achmadi, J., dan Pangestu, E., Degradasi nutrien bahan pakan limbah pertanian dalam rumen kambing secara in sacco, Jurnal Animal Agriculture, vol. 1, pp. 485-498, 2012.

12. Ørskov, E.R. and Mcdonald, I., The estimation of protein degradability in the rumen from incubation measurements weighted according to the rate of passage, J. Agric. Sci. Camb, vol. 92, pp. 499-503, 1979.

13. Steel, R.G.D. and J.H. Torrie., Principles and Procedures of Statistics, 2nd ed., McGraw-Hill., New York, 1980.

14. Agricultural and Food Research Council, Energy and Protein Requirements of Ruminants. In: AFRC Technical Committee on Responses to Nutrients, $\mathrm{CAB}$ International, Wallingford, UK, 1993.

15. Suhartanto, B., Kustantinah dan Padmowijoto, S., Degradasi in sacco bahan organik dan protein kasar empat macam bahan pakan diukur menggunakan kantong inra 
dan rowett research institute, Buletin Peternakan, vol. 24, pp. 82-93, 2000.

16. Zulkarnain, D.R., Ismartoyo dan Harfiah, Karakteristik degradasi tiga jenis pakan yang disuplementasi daun gamal (Gliricidia maculata) dalam rumen kambing secara in sacco. J. Internasional Teknik Pakan, 3, 2014.

17. Kortei, N.K. and Wiafe-Kwagyan, M., Evaluating the effect of gamma radiation on eight different agro-lignocellulose waste materials for the production of oyster mushrooms (Pleurotus eous (Berk.) Sacc. strain P-31). Croatian J. of Food Technology Biotechnology and Nutrition, vol. 9, pp. 83-90, 2014.

18. Saini, A. Neeraj, K. Aggarwal, A.S. and Anita, Y., Prospects for irradiation in cellulosic ethanol production, Biotechnology Research International, 2015.

19. Siddhuraju, P., Makkar, H.P.S. and K. Becker., The effect of ionizing radiation on antinutritional factors and the nutritional value of plant materials with reference to human and animal food. Food Chem, vol. 78, pp. 187-205, 2002.

20. Blummel, M., Makkar, H.P.S., dan Becker, $\mathrm{K}$., The in vitro gas production: a technique revisited. J. Anim Phys. Nutr., vol. 77, pp. 24-34, 1997.

21. Sutardi, T., Landasan Ilmu Nutrisi. Bogor. Fakultas Peternakan, Institut Pertanian Bogor, 1980.

22. Tang, E.X, Wang, K.Q., Cong, Z.H., Wang, M., Han, X.F., Zhou, C.S., Tan, Z.L. and Sun, Z.H., Changes in chemical composition and in vitro fermentation characters of rice straw due to gamma irradiation. J. of Food, Agriculture \& Environment, vol. 10, pp. 459-462, 2012.

23. Khan, F.S., Ahmad, R. and Kronfli E., $\gamma$ radiation induced changes in the physical and chemical properties of lignocellulose, Biomacromolecules, vol. 7, pp. 2303-2309, 2006. 
Jurnal Ilmiah Aplikasi Isotop dan Radiasi

A Scientific Journal for The Applications of Isotopes and Radiation

p ISSN 1907-0322

Vol. 13 No. 2 Desember 2017

e ISSN 2527-6433 